\title{
Financial Risk in Off-Bottom Oyster Culture along Florida's West Coast ${ }^{1}$
}

\author{
Russel Dame, Leslie N. Sturmer, Charles M. Adams, Richard Weldon, and Kelly A. Grogan²
}

\section{Introduction}

Oyster production is an important cultural and socioeconomic component of many coastal communities throughout the Gulf of Mexico. Commercial gains from the eastern oyster Crassostrea virginica in the region of Florida to Texas were derived primarily from the harvesting of wild populations and extensive (on-bottom) culture using wild, or natural, set. The Gulf region has dominated the United States harvest by volume since the early 1980s, accounting for $90 \%$ of annual landings from 2000 to 2009 , and oysters are considered a traditional fishery along the Gulf coast states (VanderKooy 2012). Despite this tradition of production and the importance to coastal economies, the region has not realized its full potential in terms of oyster aquaculture. Additionally, oyster production is highly cyclical and dependent on a number of factors (e.g., freshwater input, predator prevalence, disease, natural set of larvae, etc.). A dramatic decline in oyster landings occurred during 2012 in Apalachicola Bay, where $90 \%$ of Florida's oyster fishery was historically located. The decline was unprecedented during the period of commercial landings data (1983-2012) and likely involved recruitment failure and/or high mortality of oyster spat (Havens et al. 2013). As a result, the US Secretary of Commerce declared a commercial failure for the Florida oyster fishery. Oyster production in Apalachicola Bay has yet to recover.
With decreased supplies from the traditional fishery and higher dockside prices, the economic outlook appeared favorable for the prospects of oyster aquaculture. Further, the success of the Cedar Key clam culture industry provided a model for Florida's oyster industry in their recovery efforts (Colson and Sturmer 2000). To assist in these efforts, the Florida governor and cabinet in 2013 approved modification of hard clam aquaculture leases, which preempt only six inches above the bottom substrate for culture activities, to enable growers in Alligator Harbor (Franklin County) full use of the water column for culturing oysters. This created a new opportunity for oyster production using offbottom gear. Consequently, lease modifications for oyster cultivation have occurred in three counties on Florida's west coast and establishment of water column oyster aquaculture leases in another six counties (FDACS 2018). Though newly established and relatively small-scale, these farms will help to determine the potential of off-bottom oyster culture in Florida.

\section{Off-Bottom Oyster Culture}

In off-bottom oyster farming, hatchery-reared single-set oysters are grown in some type of mesh containers (bags, baskets, cages, etc.), which are supported in the water column above the sea bottom (Walton et al. 2013a). Suspending the gear off the bottom provides protection from predation and prevents accumulation of sediments

1. This document is FE1070, one of a series of the Food and Resource Economics Department, UF/IFAS Extension. Original publication date September 2019. Visit the EDIS website at https://edis.ifas.ufl.edu for the currently supported version of this publication.

2. Russel Dame, former graduate student, Food and Resource Economics Department; Leslie N. Sturmer, statewide shellfish UF/IFAS Extension agent IV; Charles M. Adams, retired professor, Food and Resource Economics Department; Richard Weldon, professor, Food and Resource Economics Department; and Kelly A. Grogan, associate professor, Food and Resource Economics Department; UF/IFAS Extension, Gainesville, FL 32611.

The Institute of Food and Agricultural Sciences (IFAS) is an Equal Opportunity Institution authorized to provide research, educational information and other services

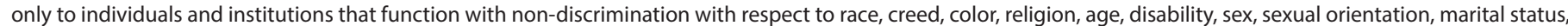

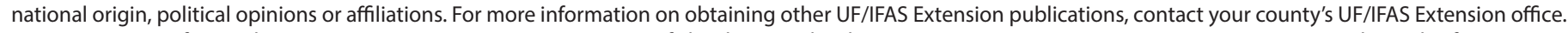
U.S. Department of Agriculture, UF/IFAS Extension Service, University of Florida, IFAS, Florida A \& M University Cooperative Extension Program, and Boards of County Commissioners Cooperating. Nick T. Place, dean for UF/IFAS Extension. 
or buryment. Other advantages to off-bottom culture include faster growth rates due to improved water flow and availability of phytoplankton (single-cell algae). Natural tumbling via wave action is another benefit of suspending gear and enables the oysters to develop a more marketable shell shape and appearance. Oysters produced using off-bottom culture techniques are typically sold to the premium half-shell market.

Three gear types are generally used in the Gulf of Mexico region for off-bottom culture-bags, cages, and adjustable longlines. Each gear type has advantages and disadvantages in operation and maintenance making it favorable or unfavorable to growers depending upon variable growing conditions. For example, floating bags are lighter and smaller than cages, allowing the grower to choose among a variety of configuration options, but the bags are more vulnerable to extreme wave or wind action due to their light weight. Floating cages, which can hold multiple bags, are heavier and adaptable to various water depths, allowing growers to sink them in place to better withstand extreme weather conditions, but the increase in weight requires an increase in labor to set up and maintain the cages. Finally, adjustable longlines may be easier to handle than floating gear, but they are limited to shallow water, and installation is more labor intensive. A review of these gear types and sample budgets for a one-acre farm in coastal Alabama is compiled by Walton et al. (2013b).

These gear types also use different methods to control biofouling. All marine aquaculture gear is vulnerable to fouling organisms, such as sea squirts, barnacles, natural oyster set, and various types of algae, which attach to the gear and product (Adams et al. 2011). Water temperatures are higher in the upper water column than on the bottom, which increases biofouling. Growers must routinely dry their gear through aerial exposure to dessicate the fouling organisms. Floating bags can be flipped over in place regularly to expose the upper surfaces of the bags (Figure 1). However, during periods of high fouling recruitment (e.g., summer months) this method may not adequately control fouling on the submerged oysters. Floating cages have larger, more buoyant floats or pontoons. When a cage is flipped from its growing position to the drying position, the enclosed bags are held out of the water, but the cage must be flipped back, requiring additional labor. The adjustable longline is similar to a floating cage in that baskets are lifted out of the water for air drying. Further development and grower experiences are needed to determine the most cost-effective and efficient gear type for a given set of site conditions.

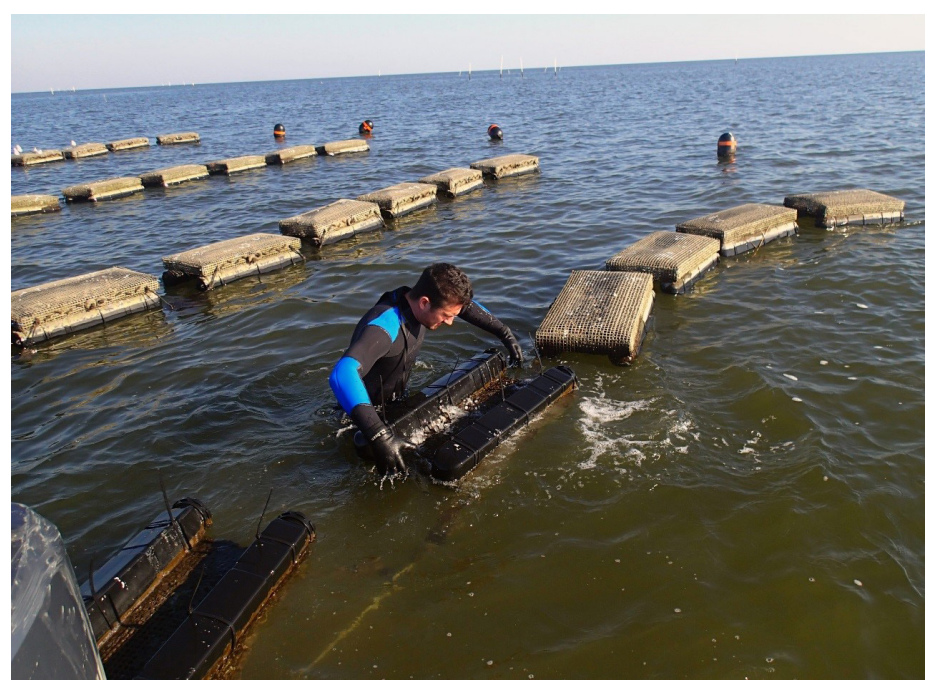

Figure 1. Lines of floating oyster bags where bags in the forground are being flipped back into the growing (submerged) position and bags in the background are in the drying position at the UF/IFAS experimental lease off Cedar Key, Florida.

\section{Risk in Off-Bottom Oyster Culture}

Agricultural risk is defined by economists as the "uncertainties inherent in weather, yields, prices, government policies, global markets, and other factors that impact farming" (USDA 2016). Examples of risk within agriculture, such as the probability of a storm destroying yields or market forces resulting in low output prices, are numerous. Farmers confront countless decisions incorporating various levels of risk throughout a production season. All farmers possess unique preferences towards and perceptions of risk, leading to various decision-making techniques and conclusions. While there is an infinite number of risk preferences, individual risk attitudes can be classified into three common categories: 1) risk-averse 2) risk-neutral and 3) risk-preferring (Hillson and Murray-Webster 2007). A risk-averse individual is uncomfortable with risk and considers most levels of uncertainty to be unfavorable. Therefore, decision-making by such an individual tends to ignore profitable opportunities and instead focuses on threats or possible losses. Risk-neutral individuals embody preferences in between risk-averse and risk-seeking preferences. Risk-neutral individuals accept risk as a necessity for future benefits leading to rational decision-making regarding threats or benefits. Risk-preferring individuals appreciate the challenge within risky decisions, sometimes underestimating risk levels and their potential impacts, leading to decisions with large risk but potentially higher payoffs.

Aquaculture is a high-risk industry that relies on external inputs, such as weather and biological processes, along with internal judgement, such as management decisions regarding labor and capital (Fleisher 1990). Because 
aquaculture is very diverse in terms of species, environments, systems, and practices, the range of hazards is wide, and the perceived risks are varied. Oyster farming, like any aquaculture or agriculture operation, has major risk sectors that are beyond the grower's control. Normal risk is related to occurrences, such as inclement weather, predation, fouling, or other variables, that typically can occur during production. Oyster mortality and costs associated with normal risk are factored into the farm's potential profitability and generally are considered acceptable at a certain level. Environmental risk in oyster farming can include events such as hurricanes, changes in food availability, or extreme changes in water quality, particularly salinity due to drought, excessive rainfall, or flooding. As environmental risk increases, potential economic impacts include increases in oyster mortality, labor time, and repair or loss of gear and equipment. Economic risk is associated with factors that directly affect the farmer's revenue, such as varying market prices, changes in input costs, and policy adjustments. For example, if market prices decrease or gear costs increase, effects on revenue and profitability may be realized. The financial characteristics of off-bottom oyster culture along the west coast of Florida were documented in order to conduct a risk assessment. Estimates of oyster production and profitability for a range of environmental and economic risk scenarios were generated.

\section{Oyster Culture Risk Assessment Methods}

As part of a research and demonstration project to understand the risks associated with off-bottom oyster aquaculture, during 2015-17 UF/IFAS faculty collected information on the costs of operating an oyster farm on the west coast of Florida. Ten farmers in four coastal counties were each provided with 5,000 triploid and diploid oyster seed and a logbook to document time (labor) associated with activities in culturing these oysters, such as planting, fouling control, transferring bags, culling/sorting, and harvesting. Three of these farmers were interviewed to provide greater background farm information so as to allow estimates of the effects various risks may have on their businesses, including potential increases in oyster mortality, labor, and capital costs. In addition, field trials replicating industry practices using the same number of seed as the participating growers were conducted at the UF experimental lease off Cedar Key. On the experimental farm, labor time associated with gear set-up and all culture activities was recorded, as well as seasonal oyster growth and mortality rates. Labor, operational and capital costs were derived from these data collection methods and applied to a hypothetical oyster farm.
Using this information, an oyster farm budget model was simulated over a five-year planning period incorporating effects of environmental and economic risks. The following assumptions were made pertaining to a small-scale farm operation. In year one, the farm was assumed to be new with 10,000 oyster seed planted. Each year the number of seed planted increased reaching 250,000 oyster seed in year five. Triploid seed (seed that have three sets of chromosomes resulting in sterility) at a size of $6 \mathrm{~mm}$ in shell height were purchased at a cost of $\$ 25$ per 1000 . The hypothetical culture system used floating bags. Vexar culture bags in three mesh sizes $(4,9$, and $14 \mathrm{~mm})$ were used in growout. The average culture unit cost was estimated at $\$ 33$ for the bag, floats, PVC pipe, rope, anchors, clips, and cable ties. Based on growers' input, the final stocking density was set at 250 oysters per $14 \mathrm{~mm}$ mesh bag, an average survival of $80 \%$ from seed to harvest (size of $65-75 \mathrm{~mm}$ in shell height) was used, and of those, $90 \%$ were marketable. The growout period was estimated to be 12 months. The model also included the purchase of a boat and motor at a cost of $\$ 32,000$ over a 10 -year loan at $7 \%$ interest. In year 1 , the owner/operator did not need part-time labor. As oyster plantings increased annually, average labor increased from 9 hours in year 2 to 126 hours in year 5 at an hourly wage of $\$ 12$. The values for each assumption used in the farm budget model, as well as the average, minimum, and maximum values affected by the normal risk variable over a five-year period are listed in Table 1.

Long-term databases available from federal and state agencies were used to predict environmental risks for oystergrowing areas on the west coast of Florida. The probability of a major storm affecting an area was determined by reviewing historical data from 1900 through 2017 from the National Oceanic and Atmospheric Association's (NOAA) interactive database, https://coast.noaa.gov/hurricanes/, which provides the name of the tropical storm or hurricane, direction traveled, wind speed, and landfall date and location (NOAA 2016). Monthly salinity data since the 1980 s were obtained for water quality stations located adjacent to oyster farms monitored by the Florida Department of Agriculture and Consumer Services (FDACS), Shellfish Environmental Assessment Section. Historical market prices of cultured oysters were not available for Florida, so prices collected by the Virginia Institute of Marine Sciences (VIMS) from 2005 to 2016 for Virginia oysters were used as a proxy. 
The environmental and economic data were analyzed under six risk scenarios to generate financial predictions for oyster- growing areas in Alligator Harbor (Franklin County), Cedar Key (Levy County), Oyster Bay (Wakulla County), and Pensacola Bay (Escambia County). In Alligator Harbor and Cedar Key, farms are also suitable for culturing hard clams Mercenaria mercenaria. Thus, start-up costs, such as surveying and marking the lease, were not applied in the financial model for these two areas. Further, a partial budgeting model for purhase of a boat and motor was used assuming that $50 \%$ of the costs were associated with the clam operation. Annual boat payments and fuel costs were divided evenly between the oyster and clam operations for farmers located in Alligator Harbor and Cedar Key. Risks were independently observed within each scenario except scenario six, which considered all environmental and economic risks.

The analysis used Simetar software, which is a Microsoft Excel add-on with a unique simulation language that contains over 230 functions, providing researchers the ability to model and simulate an industry with numerous risk variables (Richardson and Gray 2002). Simetar randomly selects values from the distribution of each risk variable and then simulates the farm budget model using the Latin Hypercube Sampling (LHS) method. The LHS method breaks each distribution into $N$ sections, where $N$ is the number of iterations, and randomly selects a value from each section. Simetar was used to simulate each oyster farm risk variable by county for each scenario. The program randomly selected a value from each potential impact for each risk scenario 1,000 times by growing location. This provided outputs of a distribution of profitability estimates for each county on an annual basis for a five-year period.

\section{Oyster Culture Risk Scenarios}

The analysis developed six scenarios that allowed for the consideration of each environmental and market risk, and a holistic scenario, which considered all environmental and market risks. This allowed for the analysis of each county's potential net return or income caused by a change in a single type of risk per scenario as well as all risk factors combined. For scenarios 1 and 5, the analysis separated the four counties into two pairs, Franklin/Levy Counties and Wakulla/Escambia Counties, because the risk was identical within each pair for these scenarios. The analysis assumed growers located in Franklin and Levy Counties owned and operated an established hard clam farming operation before investing in oyster farming. For scenarios 2, 3, 4, and 6 , each county was considered individually. For all scenarios, normal risk was applied to representative oyster farms in each of the four main oyster-producing counties along the west coast of Florida (Table 1). The probability of an environmental risk event affecting a given county is provided in Table 2.

\section{Baseline In this scenario, only normal-risk events and} conditions, such as thunderstorms, varying predation and fouling levels, and other events that occur during typical operation, were considered. Normal risk results in typical oyster mortality rates, typical labor time spent on the farm, typical repairs, and typical operational and capital costs (Table 1). Extreme environmental or market events were not included. The baseline scenario allows for comparison between other scenarios to determine the effects of environmental and economic risk variables.

\section{Hurricanes/Tropical Storms From 2015 to 2017, oyster} farms experienced three events within 60 miles of their locations. There was one category 1 hurricane traveling north (H. Irma), another category 1 hurricane traveling northeast (H. Hermine), and a tropical storm traveling northeast (T.S. Colin). The occurrence of similar events over the past 118 years was determined by searching the NOAA database so that the probability of one or two of these events affecting an oyster growing location in any given year could be calculated. There is the potential for other hurricanes with varying strengths and directions to impact oyster farms. However, only those storms that occurred during the study were considered.

\section{Low Salinities Salinity levels that fall below $10 \mathrm{ppt}$ over} two consecutive months were considered in this scenario. Salinity can be affected by excessive rainfall and runoff and/or increased flows from a freshwater source, such as a river. The timing and duration of low salinities may dramatically affect growth and mortality of different oyster sizes (La Peyre et al. 2013). The interaction of high water temperature and low salinity as opposed to low salinity alone provides a lethal combination (La Peyre et al. 2013). This analysis only considers salinity effects on oyster mortality and not effects from salinity/temperature interactions. The FDACS water quality database was searched to determine the probability of low salinities occurring at monitoring stations located adjacent to oyster-growing areas. Figure 2 depicts the probability distribution of salinities measured at monitoring stations adjacent to the Gulf Jackson lease area off Cedar Key, Florida. 


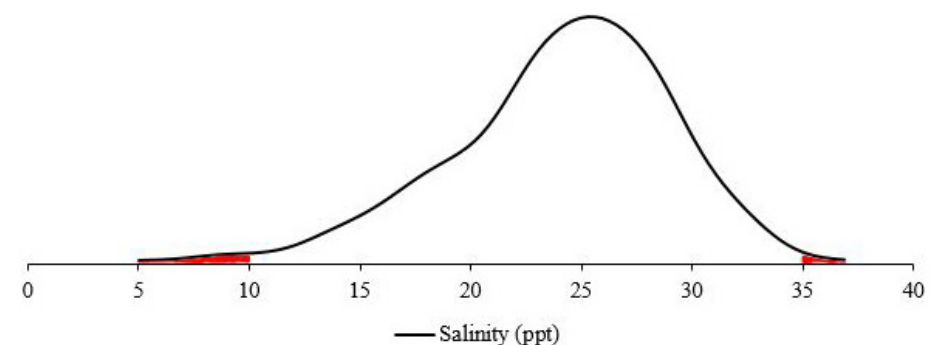

Figure 2. Distribution of salinities measured at water quality monitoring stations located adjacent to the Gulf Jackson lease area off Cedar Key, Florida. The highlighted areas represent the probability of environmental risks associated with salinities below 10 ppt or above 35 ppt. Salinities between 10 and 35 ppt represent the range in which oyster mortality is less likely to occur.

4. High Salinities Extreme high salinity events can affect oyster production due to mortalities from increased predation, pests, and diseases. Increased salinity causes a rise in oyster predators, such as the oyster drill Stramonita haemastoma and crown conch Melogena corona, and parasites, particularly Perkinsus marinus (known as Dermo), as reported in Apalachicola Bay by Menzel et al. (1966) and Havens et al. (2013). Events resulting in salinities above $35 \mathrm{ppt}$ for a period of two consecutive months were considered. Abnormally high salinities usually develop as a result of prolonged droughts. Again, the FDACS water quality database was used to determine probabilities of this type of event occurring at any of the oyster-growing locations.

5. Market Prices Historical market prices of cultured oysters from 2005 through 2016, measured in nominal dollar values, were used to create a linear regression model for predicting the expected market price per year from 2018 to 2022 (Figure 3 ). This scenario evaluated potential changes in the predicted average market price over the five-year period. Using the VIMS data for Virginia cultured oysters, the average market price in 2018 was estimated at $\$ 0.43$ increasing to $\$ 0.48$ in 2022 . The variation in the linear regression for each predicted average market price was used to create a distribution or range of prices for calculating market risk. For example, using the distribution for 2018 , prices could drop to $\$ 0.32$, but it is also possible that prices could increase to $\$ 0.55$. For each projected year, the average price increased, but the variation remained the same. The probability of market risk is the same for each county. The model expresses dollar value outputs in real 2017 dollar values.

6. All Risks A holistic approach was considered in this scenario, which factored in all normal, environmental, and market risks within an oyster-growing area. Because it is possible that any one of these risks could occur within a given year, this is a more realistic scenario. The average, minimum, and maximum effects due to an environmental or market risk event in each scenario are summarized in Table 3.

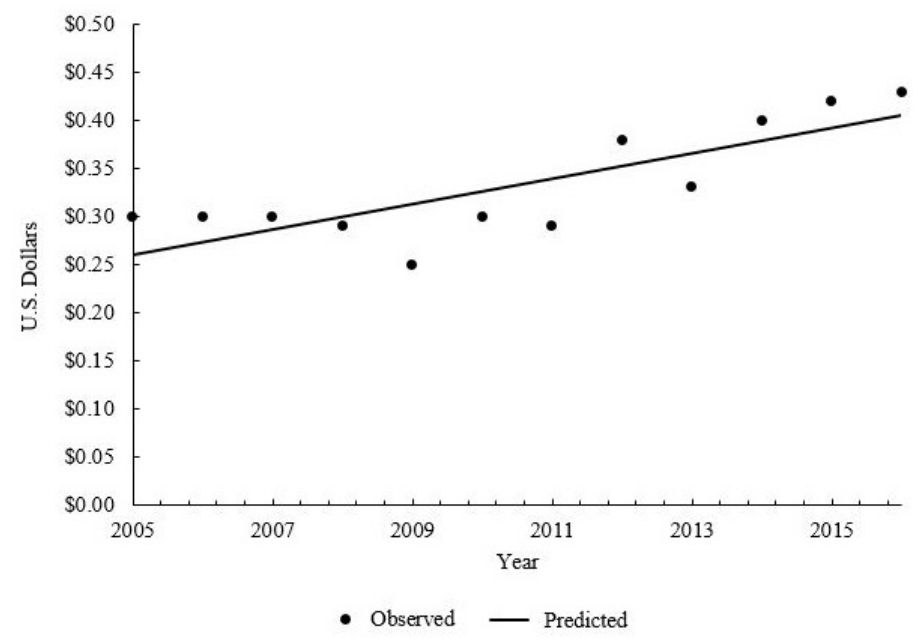

Figure 3. Linear regression model used for predicting the expected oyster market price per year from historical market prices collected from the Virginia Institute of Marine Sciences for cultured oysters from 2005 to 2016. These values are in nominal dollar amount.

\section{Oyster Culture Risk Results}

In this assessment, no additional salary is considered beyond part-time labor wages. Net returns or income refer to the profitability of a farm to the owner/operator before taxes. Additionally, the expected value is the average of all simulated net return values derived from each risk distribution. Therefore, expected net returns is the average farm profitability before taxes and owner/operator salary is taken based on the simulation results derived from each considered risk distribution.

Scenario 1: Baseline In this scenario, no abnormal environmental or economic risks were applied, just the normal risk that may typically occur in an oyster farm operation. The expected net returns at year 5 are presented in Table 4 for four counties. There are no differences between the two growing areas located in Alligator Harbor (Franklin County) and Cedar Key (Levy County) because the farming operations sustain the same normal risk, and partial budgeting was applied to these farms. The expected net return for farms in these two counties was estimated at $\$ 66,500$ with a $50 \%$ range (based on the $25^{\text {th }}$ and $75^{\text {th }}$ percentile values) of $\$ 62,500$ to $\$ 70,250$ after five years of operation. The growing areas in Oyster Bay (Wakulla County) and Pensacola Bay (Escambia County) have the same return of $\$ 63,200$, which is lower than the other two counties because clam farming was not considered in these counties. 
Scenario 2: Hurricanes/Tropical Storms Both Alligator Harbor and Cedar Key have the highest probability (19\%) of a category 1 hurricane or tropical storm heading north or northwest impacting the growing area on an annual basis. This additional risk lowers the expected net return by the end of five years to $\$ 62,440$ (Table 4 ). The higher probability of a storm striking an oyster farm affects labor time and costs due to storm preparation time, clean-up, and repairs, as well as potential increased oyster mortalities. The probability of one of these storms striking Oyster Bay or Pensacola Bay is reduced to $16 \%$ and $11 \%$, respectively. However, Oyster Bay has the highest probability (3\%) of two major storms striking within a year. The expected net return for farms located in Oyster Bay is reduced to $\$ 59,015$ at the end of five years, which incorporates the additional risk from multiple storms affecting an oyster farm in a given year.

Scenario 3: Low Salinities The highest probability of a lowsalinity event occurring in which levels fall below $10 \mathrm{ppt}$ for two consecutive months was determined to be $50 \%$ for Pensacola Bay at any given year. During this study, an actual event did occur at an oyster farm in Escambia County with resulting mortalities. This risk probability resulted in the expected net value by year 5 to decrease to $\$ 56,290$ with a range of values of $\$ 54,960$ to $\$ 65,770$ occurring $50 \%$ of the time (Table 4 ). However, $2 \%$ of the time the possibility exists that the farm operation could lose money in year five due to this risk. In Wakulla County, there was an $11 \%$ probability of a low-salinity event occurring in a production year, which would reduce the expected net value to $\$ 61,850$ in year five. At the other oyster-growing locations (Alligator Harbor and Cedar Key), probabilities of a low-salinity event occurring were zero.

Scenario 4: High Salinities The highest probability (30\%) of high salinities affecting oyster crops was in Alligator Harbor (Franklin County), which decreased the expected net value to $\$ 61,850$, a loss of about $\$ 5,000$ in revenue from the baseline scenario (Table 4). Probabilities of a high-salinity event occurring at the other growing locations were less than $1 \%$.

Scenario 5: Market Prices This scenario does not include environmental risk, only normal and market risk based on the variation of prices from projected increases over a five-year period. The average market price at the end of year five was projected to be $\$ 0.48$. This created an expected net return of $\$ 66,490$ for farms located in Alligator Harbor and Cedar Key, and \$63,220 for farms located in Oyster Bay and Pensacola Bay (Table 4).
Scenario 6: All Risks This is the most realistic scenario because it considers all risks identified in the previous scenarios. A range of net returns that would be expected 50\% of the time is based on the $25^{\text {th }}$ and $75^{\text {th }}$ percentile values. To better understand these graphs, the following discussion provides an overview of Figure 4A, which addresses potential net returns for growers in Alligator Harbor, Franklin County. Given all risks, the expected net return at year 5 is $\$ 57,959$, which is designated by the black line. There is a $50 \%$ probability of earning an income between $\$ 47,930$ (blue line, $25 \%$ ) and $\$ 68,730$ (orange line, $75 \%$ ). However, there is a $5 \%$ probability that net returns could exceed $\$ 77,890$ (green line, $95 \%$ ) or fall below $\$ 27,850$ (red line, $5 \%$ ). The expected net return of $\$ 62,440$ in year 5 for farms in Cedar Key (Levy County) is higher than Franklin County (Figure 4B). The higher return is based on a lower probability of all risks affecting farms in that county (23\%) compared to Franklin County (51\%). The highest probability of all risks affecting oyster farms occurred in Escambia County (61\%), which resulted in an expected net return of $\$ 53,850$ in year 5 (Figure $4 \mathrm{C}$ ). This is a difference of about $\$ 10,000$ in revenue from the county's baseline (no abnormal risks) projection in year 5 . The average net return in year 5 for farms in Wakulla County was $\$ 58,300$ based on a $32 \%$ probability that any risk could affect farms in that county (Figure 4D).

\section{Summary}

Due to increased plantings each year, there is an upward trend in expected net returns for years 1 through 5 as the expected quantity of oysters sold into the market increases. However, as plantings increase, the risk associated with net returns increases. All counties have a $100 \%$ probability of negative net returns at the end of year 1 as revenue does not exceed start-up costs. However, there is a greater than $98 \%$ chance that farms in all counties are profitable by the end of year 5 when all risk variables are considered.

Based on results from the simulation, oyster farms in Levy County have the greatest expected net income each year, followed by farms in Franklin, Wakulla, and Escambia Counties. The analysis assumes that Levy County oyster growers share expenses with a clam culture operation reducing total costs associated with the oyster operation, and this diversification largely causes the higher expected net returns. The lower variance results from smaller effects of environmental risk relative to all other counties. Escambia County has the lowest expected net returns and greatest variance among counties due to the high probability of a sustained low-salinity event, which has the greatest effect on mortality of the environmental risks considered. 
This financial and risk analysis was designed to assist prospective and new oyster growers to better understand the costs and earnings associated with investment in oyster culture. The analysis will also help existing hard clam growers determine the additional costs and earnings associated with incorporating oyster culture into an existing hard clam culture business. Further, these results may assist oyster growers in their decision-making pertaining to the various levels of risk that may affect their farms throughout a production season. As other hurricanes and environmental risk events occur and oyster farm damages are reported, the analysis can be updated to increase the accuracy of these risks.

A financial and risk assessment tool, Oyster Financial And Risk Model Calculator, was developed using these findings. The Microsoft Excel spreadsheet allows oyster growers to generate predictive costs and revenues for their individual farms and investment situations. The calculator can be accessed at the website, Online Resource Guide for Shellish Aquaculture, http://shellfish.ifas.ufl.edu. Financial findings are illustrated using a fan graph and stoplight chart, which determines the probability of a farm's net income falling between a range of values determined by the grower. Net income is simulated based on the farm inputs provided and probability of risk events by county. Growers can change the lower and upper bound after the simulation has occurred to determine the probability of achieving the stated net returns in the presence of all environmental and market risks.

\section{References}

Adams, C. M., S. E. Shumway, R. B. Whitlatch, and

T. Getchis. 2011. "Biofouling in marine molluscan shellfish aquaculture: a survey assessing the business and economic implications of mitigation." Journal of the World Aquaculture Society 42(2): 242-252. https://doi. org/10.1111/j.1749-7345.2011.00460.x.

Colson, S., and L. N. Sturmer. 2000. "One brief shining moment known as Clamelot: the Cedar Key story." Journal of Shellfish Research 19(1): 477-480.

FDACS. 2018. Personal communication. Florida Department of Agriculture and Consumer Services, Division of Aquaculture.

Fleisher, B. 1990. Agricultural risk management. Boulder, CO: Lynne Rienner Publishers Inc.
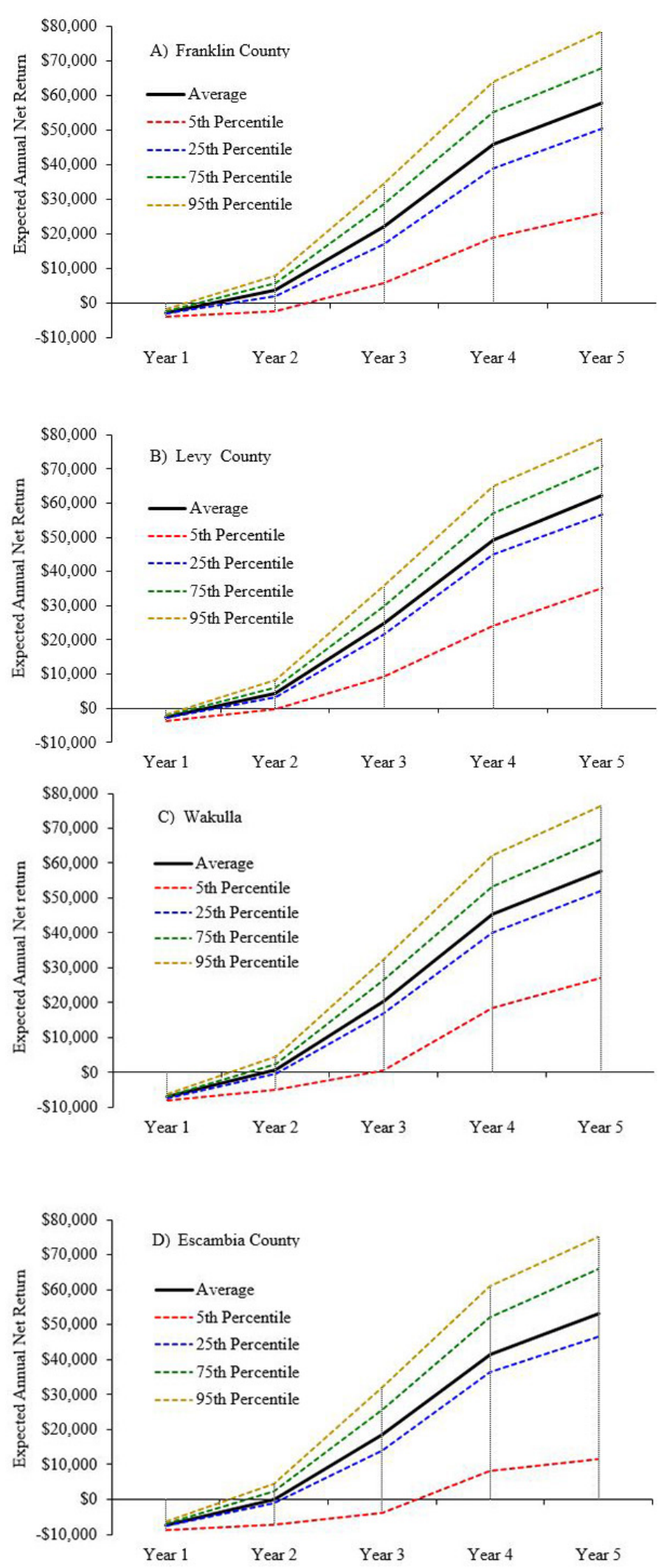

Figure 4. The expected average and potential ranges of annual net returns, or profitability, before taxes to the owner/operator of an off-bottom oyster farm located in A) Franklin County, B) Levy County, C) Wakulla County, and D) Escambia County, Florida, given all environmental and markets risks identified in Scenario 6. Each line on the graph represents the net income projected over a five-year period (2018-22) at 5, 25, 75, and 95 percentiles or probability levels. 
Havens, K., M. Allen, E. Camp, T. Irani, A. Lindsey, J. G. Morris, and C. Walters. 2013. Apalachicola Bay oyster situation report. Florida Sea Grant College Program, Technical Publication No. TP-200.

Hillson, D., and R. Murray-Webster. 2007. Understanding and Managing Risk Attitude. Gower Publishing, Ltd.

La Peyre, M. K., B. S. Eberline, T. M. Soniat, and J. F. La Peyre. 2013. "Differences in extreme low salinity timing and duration differentially affect eastern oyster (Crassostrea virginica) size class growth and mortality in Breton Sound, LA." Estuarine, Coastal and Shelf Science 135: 146-157. https://doi.org/10.1016/j.ecss.2013.10.001.

Menzel, R. W., N. C. Hulings, and R. R. Hathaway. 1966. "Oyster abundance in Apalachicola Bay, Florida in relation to biotic associations influenced by salinity and other factors." Gulf and Caribbean Research 2(2): 73-96. http:// doi.org/10.18785/grr.0202.01.

NOAA. 2016. Historical Hurricane Tracks. National Oceanic and Atmospheric Association. Retrieved from https://coast.noaa.gov/hurricanes/

Richardson, J. W., and A. W. Gray. 2002. Workshop on simulation for risk analysis. 2002 annual meeting of the Agricultural and Applied Economics Association, July 28-31, Long Beach, CA (No. 19737).

USDA. 2016. Risk in Agriculture. United States Department of Agriculture, Economic Research Service. Retrieved from https://www.ers.usda.gov/ topics/farm-practices-management/risk-management/ risk-in-agriculture/

VanderKooy, S. (editor). 2012. The Oyster Fishery of the Gulf of Mexico, United States: A Regional Management Plan-2012 Revision. Gulf States Marine Fisheries Commission, Ocean Springs, MS, Publication No. 202.

Walton, W. C., J. E. Davis, and J. E. Supan. 2013a. Offbottom culture of oysters in the Gulf of Mexico. U.S. Department of Agriculture, Southern Regional Aquaculture Center, SRAC Publication No. 4308.

Walton, W. C., J. E. Davis, G. Chaplin, S. F. Rikard, D. L. Swann, and T. Hanson. 2013b. Gulf coast off-bottom oyster farming gear types. Mississippi-Alabama Sea Grant Consortium, MASGP Publication No. 12-013-02. 
Table 1. Values, including average, minimum, and maximum, affected by the normal risk variable for each assumption used in the oyster farm budget model over a five-year period. If no value is present, then the variable takes on the average value. Normal risk is represented by potential changes in average survival, cost per growout unit, and paid part-time labor.

\begin{tabular}{|c|c|c|c|c|}
\hline Variable & Year(s) & Average & Minimum & Maximum \\
\hline \multirow[t]{5}{*}{ Oyster Seed } & 1 & 10,000 & - & - \\
\hline & 2 & 50,000 & - & - \\
\hline & 3 & 150,000 & - & - \\
\hline & 4 & 200,000 & - & - \\
\hline & 5 & 250,000 & - & - \\
\hline Oyster Seed Cost & $1-5$ & $\$ 0.25$ & - & - \\
\hline Average Survival & $1-5$ & $80 \%$ & $63 \%$ & $95 \%$ \\
\hline Percent Sold to Market & $1-5$ & $90 \%$ & - & - \\
\hline Cost per Growout Unit & $1-5$ & $\$ 32.76$ & $\$ 10.10$ & $\$ 41.42$ \\
\hline Part-time Labor & 1 & 0 & - & - \\
\hline \multirow[t]{4}{*}{ (in hours) } & 2 & 8.4 & 1 & 21 \\
\hline & 3 & 50.5 & 4 & 129 \\
\hline & 4 & 113.6 & 4 & 289 \\
\hline & 5 & 126.2 & 10 & 322 \\
\hline Wage Rate per Hour & $1-5$ & $\$ 12$ & - & - \\
\hline Annual Boat and Trailer Costs & $1-5$ & $\$ 5,440$ & - & - \\
\hline
\end{tabular}

Table 2. The probabilities of an environmental risk event affecting oyster farms located in four counties along Florida's west coast.

\begin{tabular}{|l|l|l|}
\hline \multicolumn{1}{|c|}{ Environmental Risk Event } & \multicolumn{1}{|c|}{ County } & \multicolumn{1}{|c|}{ Probability } \\
\hline Major Storms & Levy County & $19 \%$ \\
\hline & Franklin County & $19 \%$ \\
\hline Sustained High Salinity Event & Escambia County & $11 \%$ \\
\hline & Wakulla County & $16 \%$ \\
\hline Sustained Low Salinity Event & Levy County & \\
\hline & Franklin County & $30 \%$ \\
\hline & Escambia County & $0 \%$ \\
\hline & Wakulla County & \\
\hline & Levy County & $0 \%$ \\
\hline & Franklin County & $0 \%$ \\
\hline & Escambia County & $0 \%$ \\
\hline
\end{tabular}


Table 3. The average, minimum, and maximum effects to oyster mortality and price due to an environmental or market risk event in scenarios 2 through 5 are summarized.

\begin{tabular}{|c|c|c|c|c|}
\hline Scenario & Risk Event & Average & Minimum & Maximum \\
\hline & Major Storms or Hurricanes & & & \\
\hline \multirow[t]{4}{*}{2} & Additional capital from major storms & $33 \%$ & $20 \%$ & $40 \%$ \\
\hline & Additional labor from major storms & $34 \%$ & $18 \%$ & $43 \%$ \\
\hline & Mortality from major storms & $8 \%$ & $0 \%$ & $30 \%$ \\
\hline & Sustained High Salinity Event & & & \\
\hline \multirow[t]{4}{*}{3} & Additional capital from high salinity & $10 \%$ & $0 \%$ & $30 \%$ \\
\hline & Additional labor from high salinity & $26 \%$ & $20 \%$ & $30 \%$ \\
\hline & Mortality from high salinity & $10 \%$ & $0 \%$ & $20 \%$ \\
\hline & Sustained Low Salinity Event & & & \\
\hline \multirow[t]{4}{*}{4} & Additional capital from low salinity & $0 \%$ & $0 \%$ & $0 \%$ \\
\hline & Additional labor from low salinity & $4 \%$ & $0 \%$ & $15 \%$ \\
\hline & Mortality from low salinity & $12 \%$ & $0 \%$ & $89 \%$ \\
\hline & Market Price per Oyster & & & \\
\hline \multirow[t]{5}{*}{5} & Year 1 & $\$ 0.43$ & $\$ 0.32$ & $\$ 0.55$ \\
\hline & Year 2 & $\$ 0.45$ & $\$ 0.33$ & $\$ 0.56$ \\
\hline & Year 3 & $\$ 0.46$ & $\$ 0.34$ & $\$ 0.58$ \\
\hline & Year 4 & $\$ 0.47$ & $\$ 0.36$ & $\$ 0.59$ \\
\hline & Year 5 & $\$ 0.48$ & $\$ 0.37$ & $\$ 0.60$ \\
\hline
\end{tabular}

Table 4. Potential net returns or incomes to the owner/operator at the end of a five-year period for baseline, environmental, and economic risks associated with off-bottom oyster farms located in four counties on the west coast of Florida. The expected value is the average of all the simulated net income values derived from each risk distribution. A range of net returns that would be expected $50 \%$ of the time, based on the 25 th and 75 th percentile values, is presented.

\begin{tabular}{|c|c|c|c|}
\hline \multirow[t]{2}{*}{ Risk } & \multirow[t]{2}{*}{ County } & \multicolumn{2}{|c|}{ Net Income (\$) } \\
\hline & & Expected & Range (50\%) \\
\hline \multirow[t]{2}{*}{ Baseline } & Franklin/Levy & 66,181 & $62,547-69,850$ \\
\hline & Wakulla/Escambia & 62,565 & $58,598-66,349$ \\
\hline \multirow[t]{4}{*}{ Hurricane/Tropical Storms } & Franklin & 62,412 & $58,971-69,048$ \\
\hline & Levy & 62,139 & $59,318-69,015$ \\
\hline & Wakulla & 59,019 & $56,427-65,319$ \\
\hline & Escambia & 60,114 & $56,937-65,727$ \\
\hline \multirow[t]{2}{*}{ Low Salinities } & Wakulla & 61,212 & $58,021-66,073$ \\
\hline & Escambia & 55,652 & $54,324-65,131$ \\
\hline High Salinities & Franklin & 61,531 & $57,791-68,776$ \\
\hline \multirow[t]{2}{*}{ Market Prices } & Franklin/Levy & 66,169 & $60,432-72,223$ \\
\hline & Wakulla/Escambia & 62,560 & $56,620-68,302$ \\
\hline
\end{tabular}

